\title{
LOCAL GOVERNMENT AND SUSTAINABLE URBANISATION IN NIGERIA
} https://doi.org/10.47743/jopafl-2021-20-15

\author{
Abiodun Richard OBISANYA \\ Department of Public Administration, Lagos State University, \\ Ojo, Nigeria \\ richymytime@yahoo.com \\ Korede Ibrahim HASSAN \\ Department of Public Administration, Lagos State University, \\ Ojo, Nigeria \\ hassankorede00@gmail.com \\ Philip Oche MUSA \\ Dept of Public Administration. Federal Polytechnic Ilaro \\ Ilaro, Nigeria \\ musaphilipoche@gmail.com
}

\begin{abstract}
The ever-rising increase in growth and complexities of human settlement, particularly the rate of urbanization have created new challenges in the 21 century as several national governments continue to strive to attain sustainable development and effective urban governance. The objective of this study is to access the role of the local government in engendering sustainable urban governance in Nigeria. The study adopted an exploratory research design with the use of secondary data from 2010 to 2018 and the projection of rural urban growth by 2025.Content analysis was employed as data analysis method. Using the modernization theory, the study discovered that the problem of urbanization is global but in Nigeria its administration is uncoordinated and fragmented with inadequate urban administrative tools. It discovered that the local government in Nigeria are given little or no technical or financial capacity to govern urban areas. It recommends a bottom -top approach in planning of urban administration that is inclusive of the local government. Also, it suggests that the policies formulated and implemented should be tailored towards addressing the problems of urban growth. The study concluded that a participatory, multi stakeholders, collaborative approach to policy making and implementation in urban administration is the key to achieving an ideal sustainability of urban centres in Nigeria.
\end{abstract}

Keyword: Local Government, Sustainable Development, Urbanization, Population Growth And Administration.

\section{Introduction}

One of the critical issues of concern to most national governments world over is the need to stem the rate of urbanization induced by the incidence of globalization, industrialization and an unprecedented population growth rate in the cities (Osasona et al., 2017). This concern has led to several global Summits organized at various level of government, international Agencies including the United Nations. Specifically among such are, the Millennium Development Goals Summits, the 2002 world summit in Johannesburg and the 2005 La-Havana UN sustainable cities documentation of experience programme among several others. In each of these summits, member nations reiterate the need for good 
and effective governance as a means of achieving sustainable development in the cities. (Oladunjoye, 2005). The pervasiveness and spontaneity of the global Urbanization process has been an issue of concern in recent time; as this essentially constitutes serious challenge to the attainment of sustainable development and effective urban governance. Since the early 1950s rapid urbanization has been a characteristic feature of Nigeria. Recent demographic studies show that urban areas constitute about half of the national population (Oyesiku et al, 2018). The inclusion of the urbanization factor in determining the post-2015 global development agenda is therefore fundamental if evolving positive processes, salient contextual factors, and the powerful momentum prevailing at this advent of the new millennium are to be harnessed. In addressing the urbanization phenomenon, a post-2015 UN development agenda should go beyond the demographic dimension and should address the main challenges and opportunities that are shaping twenty-first century cities and towns, including how this affect and contribute to sustainable development.

In Nigeria, the urbanization process is similar to what obtains in several other developing countries; as the growth and complexity of human settlements and in particular the rate of urbanization has been phenomenal (Ujoh et al., 2018). Considering its 2016 population figure of over 140 million people - the highest in Sub-Saharan Africa (Ajanlekoko,2001) in Akinwotu (2017); available data however shows that the country has been growing at the rate of 5.5 percent annually from 1980 to 1993, and recently, its growth has increased to the rate of 5.8 percent, which has resulted in a total urban population of 62.66 million people (or, 43 percent of the national population). By projection, this proportion is expected to increase to more than 60 percent by 2025 (UN, 2017).

\section{Statement of the problem}

The world is in the midst of an unprecedented expansion of human numbers. In the 21st century, urbanization has "created new challenges, such as climate change, depletion in resources, food insecurity, social and spatial inequalities, economic instability, urban sprawl, and unplanned urbanization” (FGN, 2018). Hence, Akinwotu (2017) posits that the urban-poor and urban-rich development dichotomy has continued to constitute a serious humanitarian crisis to Nigeria and by extension, the entire global developmental discourse. As Prahalad and Hammond (2002) and Cohen (2016) in Adegun (2019) contends, urban areas have presently accommodated more than half of the global population and over the next 30 years, it is projected to grow to over two billion populations majorly in the developing countries. Nigeria, like other developing countries, is faced with increased rate of urbanization, with different urban centres emerging as a result. Egboje (2018) observes that this overcrowding situation has created increased pressure on few available critical socio-economic infrastructures, and systems. In addition, Nigeria, as World Bank writes in 2017, the population of the lives in low-cost settings and slums of urban centres, is about 85\%. Comprehensibly, the description of urban-slums does not easily appear in the analysis of public programmes, policies and projects distributions which are overwhelmingly metropolitan. Ofuebe (1992) therefore situates Nigerian governments to have always been involved erroneously in an insistence on the inevitability of the provision of amenities for the poor as a counterpoise to the amelioration of her underdevelopment. The design and implementation of the National Urban Development Policy in Nigeria were the prerogative of elite groups who resides in the developed part of the urban core. Consequently, "the 
failure to effectively implement the 1992 National Urban Policy and consequently, the National urban development policy of 2012 had to do with the fact that majority of the actors responsible for the implementation were found to either not to be fully aware of their roles and responsibilities; or did not have the requisite knowledge and capacity; or were simply not left out of the implementation process.

In Nigeria, there appear to be a disconnect between natural population growth rate and urban growth rate of over 5\% (Azu 2018). Nigerian cities lack official recognition by the government, and no city in Nigeria is incorporated as many of them are merged with rural areas in the same undifferentiated system of 774 local governments (Adegun 2019). Yet, despite clear physical evidence of urbanization, it must be noted there are large uncertainties in Nigeria's population projections and the implication on local government administration. From the review of the literature, it is clear that most of the urbanization studies done in Nigeria virtually excluded the role of local government in addressing the challenges of urbanization. This is the gap this study seeks to fill.

\section{Objective of the study}

The study seeks to access the role of local government in urban governance. Specifically, this study seeks to investigate the reason for the neglect of local government in urban planning policies, implementation in Nigeria and how it can help to engender sustainable urbanization.

\section{CONCEPTUAL REVIEW}

\section{Local government}

The term "Local Government" literally means management of the local affairs by the people of the locality. It is based on the principle that the local problems and needs can be looked by the people of the locality better than by central or state governments. Appadorai (1975) see "Local Government is a government by popularly elected bodies charged with administration and executive duties in matters concerning the inhabitants of a particular district or place.” Ajayi (2000) defines local government as "a territorial non sovereign community possessing the legal right and the necessary organ to regulates its own affairs, which presupposes the existence of a local authority with the power to act independently both external control as well as the participation of the local community in the administration of its own affairs through representation”. According to Aijaz (2017)in Daramola \& Ibem (2018) local government is part of the government of a country which deals mainly with problems or issues related to a given population within a given territory. This is done basically on the responsibilities of a country that parliament decides to delegate by the laws to local governance. In this definition we find two important elements of local government, that of the existence of directly elected local bodies and local finances, which constitute common denominators of each local government. While Lockard (Lockard,1963) in Adesina (2003) thinks that the local government can be defined as a public organization, authorized to establish and administer public policies within a given territory, the latter is a subdivision of the central government. In fact the organization of local government is public organization, changing from private organizations, they are aimed at the general interest of citizens. Enemuo (2008) conceive local government thus: 
... the lower level of government in a modern state, that is legally distinct, and has powers to raise revenue and undertake assigned responsibilities under a leadership that is elected and answerable to the local population . The various definitions above are quite revealing and far-reaching as they shed much light on the meaning, significance, and jurisdiction of local government administration.

\section{Sustainable Urbanization}

Urbanization as used in this paper to describes the process by which cities grow or by which societies become more urban. It also means the process by which more and more people leave the countryside to live in cities (Azu, 2018). Ayoade (2016) noted that urbanization undoubtedly represents human's greatest impact on natural environment. Fields, farms and forest are replaced by stones, bricks concrete and asphalt. Cities are characterized by large concentration of people, vehicles, buildings and other forms of modern artefacts. In the same sense, the United Nations Secretariat (1970) noted that urbanization is perhaps, the best symbol of the radical, physical, economic and social transformation that mankind is passing through as a consequence of development (Duru \& Ogbonnaya; 2012). Urbanization is driven by the concentration of investment and employment opportunities in urban areas. In these areas, secure tenure is a necessary condition to improve access to economic opportunity, including livelihoods, credit markets, public and municipal services. When tenure rights are insecure people have reduced incentives to invest in and upgrade land and housing; they may be forced to leave a family member home to guard property rather than work or go to school; and, they may often lack access to services to devote significant portions of their time and income to acquire these.

Sustainable Urbanization Strategy outlines how UNDP is responding to rapid urbanization in developing countries and its consequences for sustainable development. It outlines how UNDP will support countries and cities, building upon its past and current work on urbanization. The strategy presents the complex and evolving urban challenges and the interrelated development choices which cities face as they strive to achieve the SDGs and implement the New Urban Agenda. It also sets out UNDP's comparative advantage and experience in core thematic areas which are relevant to achieving the SDGs in cities and urban areas. Put more succinctly, goal 11 in SDGs 2015 captures the essence of sustainable urbanization " To make cities and human settlements inclusive, safe, resilient and sustainable" It also states that by 2020,there will be substantial increase in the number of cities and human settlements adopting and implementing integrated policies and plans towards inclusion, resource efficiency, mitigation and adaptation to climate change and resilience to disasters. (UNDESA 2018)

\section{THEORETICAL REVIEW}

\section{Modernization Theory}

This theory was prevalent and influential from the 1950s the 1970s. The theory asserts that urbanization results from the introduction of new things and innovations within the society through industrialization, technological application, information penetration and cultural diffusion (Smith, 1996). Considering urbanization through the lens of modernization, first, it is common to see elements of modernization (new things) in every 
society that has moved from the primitive era (Stone Age) to a new or modern pattern of doing things. Secondly, the importance of technology in social organization and shaping of the society is very obvious; as urbanization usually results afterwards. The present state of urbanization and development in the world today cannot be separated from its initial state at the onset of modernization (Kasarda\&Crenshaw, 1991). Most developments are products of technologically driven societies, which could boost or increase economic capabilities, provide surplus food through improve agricultural system and the use of mechanical and electronic tools or machines to reduce workload on citizen; yet increasing speed and efficiency of work done (Lenski \& Nolan, 1984; Nolan \& Lenski, 1985). It is assumed in this context that technology is more important than social organization of the society. Thus, the application of technology is seen as the main driving force of urbanization in the society. According to Kasarda \& Crenshaw (1991); industrialization rather than capitalization is often seen by scholars in this tradition as having major impact in the transformation of the third world societies. Previous scholars have asserted that the modernization approach encourages cultural diffusion and breeds uneven development especially in the third world countries (Hawley, 1981; Kasarda \&Crenshaw, 1991). It is believed that this kind of urbanisation may have been triggered by the concentration of social amenities and developmental projects in certain parts of the society, due to ethnic, racial or religious divisions and corrupt politics, that has created economic dichotomy and uneven developments in the world today (Alonso, 1980). With investments and opportunities concentrated in few places (most likely cities); massive rural-to urban migration is necessitated stemming from rural-push and urban-pull factors (Berliner, 1977; Kasarda \& Crenshaw, 1991).

\section{Urban and rural areas: a distinction}

Human settlements are classified as rural or urban depending on the density of human-created structures and resident people in a particular area. Urban areas can include town and cities while rural areas include villages and hamlets. While rural areas may develop randomly on the basis of natural vegetation and fauna available in a region, urban settlements are proper, planned settlements built up according to a process called urbanization. Many times, rural areas are focused upon by governments and development agencies and turned into urban areas (Conroy,2017) in Egboje (2018). Urban settlements are defined by their advanced civic amenities, opportunities for education, facilities for transport, business and social interaction and overall better standard of living. Sociocultural statistics are usually based on an urban population. While rural settlements are based more on natural resources and events, the urban population receives the benefits of man's advancements in the areas of science and technology and is not nature-dependent for its day to day functions (McCann, 2017) in Egboje (2018).

In terms of level of economic development, quality of life, access to opportunities, facilities and amenities, standard of living and general viability, the gap between the urban and rural areas in Nigeria is very wide. The rural areas are grossly neglected as far as development projects and infrastructure are concerned. The consumption oriented urban economy is flooded with people many of who are either unemployed or unemployable, or marginally employed or underemployed in the urban centres where they choose to live. As a result of this mass exodus, the rural areas have become qualitatively depopulated and are 
progressively less attractive for social and economic investments while the urban areas are becoming physically congested, socially unhealthy and generally uneconomic to maintain (Adedire, 2014).

Major differences between rural and urban societies

\begin{tabular}{|c|c|c|}
\hline $\mathrm{S} / \mathrm{N}$ & Rural Areas & Urban Areas \\
\hline 1 & $\begin{array}{l}\text { Life in the society was very simple and } \\
\text { reflected in the way of living, dressing, } \\
\text { food habits, shelter and manners etc. }\end{array}$ & $\begin{array}{l}\text { Life in the city is not simple but very complex and } \\
\text { complicated. }\end{array}$ \\
\hline 2 & $\begin{array}{l}\text { The people in the society had } \\
\text { homogeneity and thus enjoyed more or } \\
\text { less the same social status. }\end{array}$ & $\begin{array}{l}\text { The people in the city belong to different castes, } \\
\text { creeds, religions and cultures, thus do not enjoy the } \\
\text { same social status. }\end{array}$ \\
\hline 3 & $\begin{array}{l}\text { In the rural society there was very little } \\
\text { scope for occupational mobility. }\end{array}$ & $\begin{array}{l}\text { In cities there are many occupations, so occupational } \\
\text { mobility is as well as frequent. }\end{array}$ \\
\hline 4 & $\begin{array}{l}\text { Here the family played a very significant } \\
\text { and predominant role. Its hold was very } \\
\text { strong. }\end{array}$ & $\begin{array}{l}\text { In the cities hold of families is not strong, and many } \\
\text { functions which the families used to perform have } \\
\text { been taken away by other institutions and } \\
\text { associations. }\end{array}$ \\
\hline 5 & $\begin{array}{l}\text { In villages there is no fast change and as } \\
\text { such no necessity for social adaptability. }\end{array}$ & $\begin{array}{l}\text { In the cities there must be fast mobility and } \\
\text { adaptability to suit ever changing fast life. }\end{array}$ \\
\hline 6 & $\begin{array}{l}\text { In the rural society culture was very } \\
\text { deep-rooted. Everyone loved culture and } \\
\text { cultural heritage above everything else. }\end{array}$ & In the cities it is difficult to find pure culture. \\
\hline 7 & $\begin{array}{l}\text { In a rural society there is no division of } \\
\text { labour. }\end{array}$ & $\begin{array}{c}\text { In an urban community there is always division of } \\
\text { labour and specialisation in job allotment. }\end{array}$ \\
\hline 8 & $\begin{array}{l}\text { Rural society did not give due and proper } \\
\text { respect to the womenfolk. }\end{array}$ & $\begin{array}{l}\text { In urban communities women enjoys comparatively } \\
\text { high social status. }\end{array}$ \\
\hline 9 & $\begin{array}{c}\text { In this society people loved nature and } \\
\text { natural bounties. They were religious } \\
\text { minded and afraid of gods and } \\
\text { goddesses. }\end{array}$ & $\begin{array}{c}\text { In cities, people have no time to stand and gaze at the } \\
\text { nature. They are not religious minded but more } \\
\text { materialistic. }\end{array}$ \\
\hline 10 & $\begin{array}{l}\text { There were very few chances of } \\
\text { providing employment and incentives to } \\
\text { the unemployed by the society. }\end{array}$ & $\begin{array}{l}\text { The cities provide both incentive and employment to } \\
\text { the people and thus frustrated villages find solace in } \\
\text { the cities which respects ability and judges their } \\
\text { worth. }\end{array}$ \\
\hline
\end{tabular}

Source: adapted from https://www.yourarticlelibrary.com/society/10-major-differences-between-rural-andurban-societies/23390

\section{The challenges of urbanization in Nigeria}

Urbanization is a "process of human agglomeration in multi-functional settlement of relatively substantial size” (Mabogunje, 1985). According to Ujoh et al., (2018), it is the process that refers to the growth both in size and numbers of urban centre. This process, as explained by Adesina (2003), has been responsible for transforming towns, cities and metropolitan areas, while at the same time depopulating the rural setting through a process of direct rural-urban migration. Adegun (2019) describes the level of urbanization as the share of a country's total population that lives in urban areas. Thus, the extension of the urban environment in terms of territorial coverage and population has remained a common experience all over the world; while the proliferation of urban centre has been phenomenal from the turn of the 20th century (European Environment Agency, 2016). However, urban extension did not take place in the third world cities until after the Second World War when 
such became European Colonial Settlements. In most part of Africa, even Asia and Latin America, strategic cities along the coast, for many decades represented trade point and gateways for export and import. These cities continuously improved in economic activities through time, and subsequently transformed to industrial cities. Today, urban centre dominates African countries landscape with their attendant opportunities.

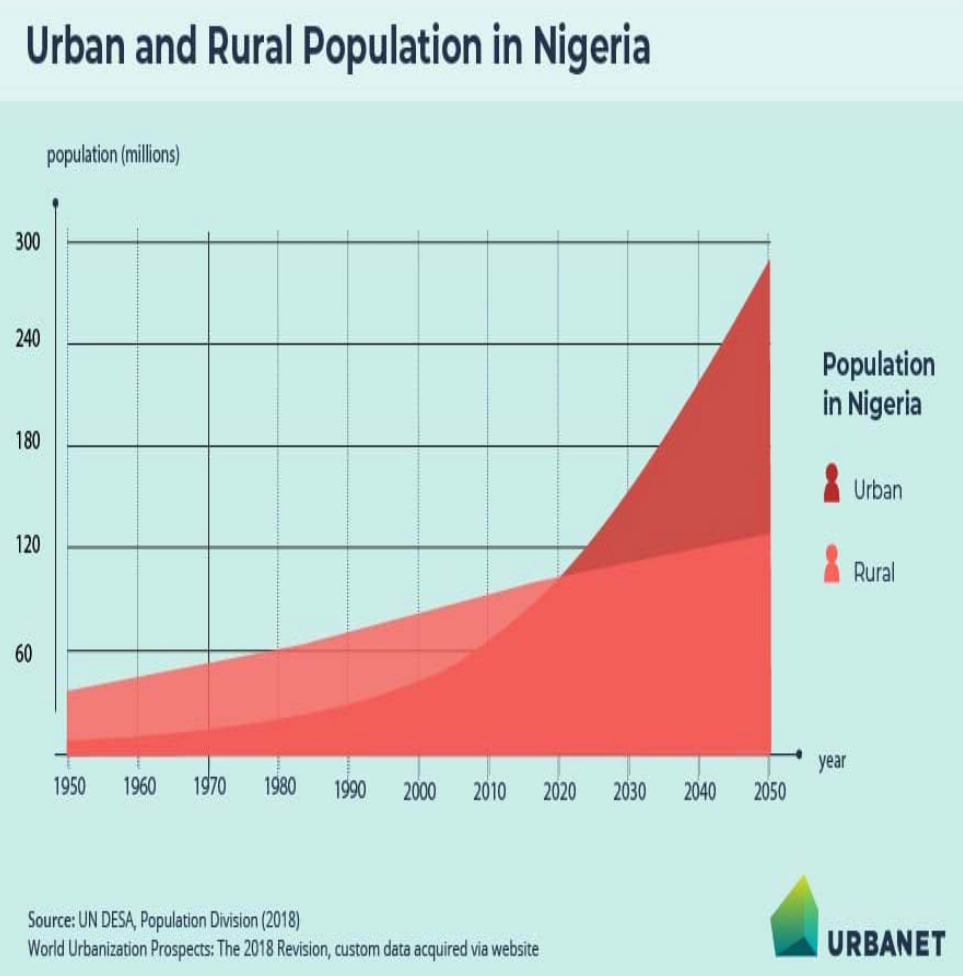

The graphic displays the expected linear growth of Nigeria's rural population since 1950 until 2050. The urban population has been experiencing a rapid rise since 2018 and is expected to grow from 60 million to almost 300 million inhabitants in Nigerian cities. The United Nations Fund for Population Activities (UNFPA) during the 1999 World Habitat day confirmed that urban revolution has begun of which Africa and other developing countries would have to face great challenges. The fastest population growth would take place in Africa, and this has continued to grow over the years, from 133miliion in 1900 to 225milion in 1950; while there were about 674million people in 2000. The population is expected to continue to increase to 1.5 billion in 2030, with the annual growth rate of about 2.1 percent (Adegun, 2019). This population rise would take place mostly in the cities. However, the United Nations demographic experts have estimated Africa's annual urban growth rate at about 5.3\% in 1980 and 3.4\% in 2000. The region's urban population grew from 32 million in 1950 (15 percent of the region's entire population) to 102 million in 1975 and 220 million in 2000 (33 percent of the region's entire population). Current figure as at 2018 indicates that the number of city dwellers on the continent now stands at 321 million (about 40 percent of the region's entire population). This is projected to reach 787 million by 2030; - thereby crossing the 50 percent urban threshold sometime before 2025 and reaching 53 percent by 2030, (United Nations, 2002; Adegun, 2019). 
In the post independence era, starting from 1960, people in Nigeria kept migrating at an increasing rate from the rural areas to the urban centres in pursuit of better living conditions. Like every other nation of the world, the migration has been causing rapid and extensive growth in the urban centres creating many problems of urbanization presented in pictures below. The urban population in Nigeria has grown from 6.9 million, $15.4 \%$ of the total population of 45 million in 1960 to 99.9 million, which is $48.9 \%$ of the total population of 195.8 million today. The figure below shows the population growth in Nigeria between 1960 to 2018

Nigeria's Rural and Urban Population, 1950-2025

\begin{tabular}{|l|c|c|c|}
\hline Year & Rural Population & Urban Population & Urban Population as \% of Total \\
\hline 1950 & $29,595,000$ & $3,340,000$ & 10.1 \\
\hline 1955 & $32,605,000$ & $4,489,000$ & 12.1 \\
\hline 1960 & $36,220,000$ & $6,058,000$ & 14.3 \\
\hline 1965 & $40,396,000$ & $8,280,000$ & 17.0 \\
\hline 1970 & $45,252,000$ & $11,319,000$ & 20.0 \\
\hline 1975 & $50,835,000$ & $15,511,000$ & 23.4 \\
\hline 1980 & $57,188,000$ & $21,242,000$ & 27.1 \\
\hline 1985 & $63,448,000$ & $28,568,000$ & 30.9 \\
\hline 1990 & $70,383,000$ & $38,159,000$ & 35.2 \\
\hline 1995 & $77,533,000$ & 50,16200 & 39.3 \\
\hline 2000 & $84,853,000$ & $64,768,000$ & 43.3 \\
\hline 2005 & $91,960,000$ & $82,347,000$ & 47.2 \\
\hline 2010 & $98,435,000$ & $102,831,000$ & 51.1 \\
\hline 2015 & $103,411,000$ & $125,343,000$ & 54.8 \\
\hline 2020 & $106,458,000$ & $148,935,000$ & 58.3 \\
\hline 2025 & $107,758,000$ & $173,135,000$ & 61.6 \\
\hline
\end{tabular}

Source; UNDESA Population Division 2018

Urbanization is not a new phenomenon in Africa, as cities such as Lagos, Kano, Ibadan, Cairo, Johannesburg, Kinshasha and Addis Ababa, have grown to become large metropolitan urban areas. The city of Lagos for instance, has continued to grow in size since the 1960s; its annual growth rate was close to 14 percent during the 1970s, when the massive extent of new construction was exceeded by the influx of migrants attracted by the oil boom. Acknowledged to be the largest city in sub-Saharan Africa, Lagos has become legendary for its congestion and other associated urban problems. Essentially built on poorly drained marshlands, the city commonly has flooding during the rainy season, and there is frequent sewage back-up, especially in the poorer lowland sections. As in other Nigerian cities, there is a constant problem of garbage and waste disposal. Housing construction has boomed but rarely seemed to keep pace with demand. The city's main fame, however, comes from the scale of its traffic jams; spanning several islands as well as a large and expanding mainland area, the city never seemed to have enough bridges or arteries. The profusion of vehicles that came with the prosperity of the 1970s seemed often to be arranged in a massive standstill, which has become the site for urban peddling of an amazing variety of goods, as well as for entertainment, exasperation, innovation, and occasionally crime (Abiodun, 1997). By 1990, Lagos had made some progress in managing 
its traffic problems both through road and bridge construction and traffic control regulations. This progress was aided by the economic downturn of the late 1980s, which ironically, facilitated urban - rural migration (Metz, 1991) in Abiodun(1997). However, it has been projected that by 2015, the population of Lagos in Nigeria will be around 24.3 million; thereby ranking it as the third largest city in the world. This trend of growth puts strain on the city where most resources will be consumed and this process thus constitutes a critical challenge to sustainability in Nigeria (Adesina, 2003; Adegun, 2019).

The aforementioned urbanization problems birthed the revised National urban development policy of 2012, its major aim: 'to promote a dynamic system of clearly defined urban settlements, which fosters sustainable economic growth, promotes efficient urban and regional planning and development ,as well as ensures improved standard of healthy living and the well-being of all Nigerians'(UNDAP 2015). This aims were based on the following strategic goals:

(1) Facilitate private sector led delivery of 800,000 homes per annum over the next 10 years

(2) Facilitate the implementation of special housing programs to promote the delivery of 200,000 units per annum for the next 10 years

(3) Establish an information management system for planning, implementation, monitoring and evaluation of programs and projects

(4) Establish and enforce use of building standards in line with the national building code to ensure quality, functionality, aesthetics and safety

(5) Make serviced land with secure tenure easily available, accessible, transferable and at affordable price for housing development

(6) Build adequate capacity of professionals and artisans in the built environment sector

(7) Make cities and human settlement inclusive, productive, safe, livable, resilient and sustainable

(8) Transform the way the Federal ministry of lands, housing and urban development is structured and operates as the industry regulator and facilitator

(9) Promote research and development. (UNDAP 2015)

There is no doubt that Nigeria as a nation is experiencing rapid urbanization which has brought about various socio - economic, cultural and environmental problems, particularly, degradation of the physical urban environment which exists in the nature of loss of biodiversity and green-house warming, desertification, degradation of agricultural land, air and water pollution, environmental decay, slums, insanitation, overcrowding, housing congestion, crime and violence, and several other demeaning situations (Jiboye \& Omoniyi, 2018; Daramola \& Ibem, 2018). Considering the challenges posed by the diverse problems associated with urbanization and the need for sustainable development in Nigeria, urgent step is required on the part of government in particular and other stakeholders responsible for urban development, through effective governance to control the rate at which urban population and the spread of cities increases. Also, effort is required to control the decline in the quality of urban infrastructure as well as improve the overall standard of living of the people in Nigeria.

\section{Local government and urban administration in Nigeria}

In the contemporary world today, the need to decentralize administration to facilitate efficiency, effectiveness and good governance has become the rule rather than the 
exception. Both developed and developing countries ensure that services are delivered to the people. It is no doubt that these services are delivered via a structure put in place by these countries, which are given different names. In Nigeria, it is called local government. Local government administration is said to be the third tier of government that is closer to the people in any country amongst the three tiers of government. The rapid urbanization in developing countries particularly in sub Saharan African societies like Nigeria requires more proactive and efficient actions to ensure its sustainability. Therefore, effective local government administration has been identified as a sine qua non to achieving sustainable development through the creation of enabling environment in which every member of the society can enjoy good health and creative lives. The management of towns and cities in Africa is part and parcel of the public sector management system of government inherited from the colonial era. Towns and cities operate through elected and appointed local government representatives, who have the political and administrative mandates to provide and manage social and physical infrastructure services. The powers of local governments are provided by central government (state/federal governments) and within the model there are variations in terms of the nature of local government structures and centre-local relationships. The role of local government is often further complicated by the key position it plays in the patronage system of political parties and by the widespread phenomenon of African cities often being the bases of political parties in opposition to national governments led by parties with a largely rural support base (Obeng-Odoom, 2017).

In most countries, urban areas are the engines of economic growth and provide spaces for social transformation and political inclusion. This is the case because dynamic and prosperous cities are able to attract and retain both the talent and the capital investments necessary to attract businesses and sustain high productivity levels by offering high quality urban services and infrastructure. The delivery of widely accessible and efficiently functioning basic services is thus essential for urban areas to realize their full economic growth potential. As a result, the degree of success with which a country harnesses the power of urbanization serves as an important bellwether for inclusive and sustainable development. The urban administration in Nigeria is characterized by a fragmentation and sometimes duplication of functions. Local governments are left with little technical and financial capacity to govern urban spaces in an integrated way. Being the third tier of government, the funds allocated to them are often "hijacked by the state government". State governors generally play the role of urban administrators but concentrate their efforts on large cities.

In many countries of the world, the role of different levels of government in providing infrastructure has been the subject of detailed debate. For instance, Obot \& Umoh (2017) argued that the planning, development and maintenance of public infrastructure are the primary responsibility of the three tiers of government, with the federal government having the greatest share of the responsibility, while Yamihinmi (2016) \& Adele (2003) in Adegun (2019) posited that the local governments are least able to response to these functions because they are grossly underfunded, lack fund generating drive, technical expertise and other resources to provide for. Urban administration in Nigeria is largely uncoordinated, fragmented and lacked focus mostly due to inadequate urban administration tools such as spatial data and map products and poor legal framework (Fabiyi, 2014). Urban administration in Nigeria has been disjointed and uncoordinated. The United Nations Human Settlements Programme reports (UNHABITAT) indicated that 
virtually all the cities in Nigeria fell below average in good urban governance index (GUGI). Bamidele (2008) identified the inefficiency of the state government to properly manage urban settlements and called for federal government presence in the cities in terms of infrastructural developments. Most local government areas have no financial capacities to manage urban settlements. Though the local government area is the third tier of governance in Nigeria, the funds allocated are often hijacked by the state government and local government area administrations are left with paltry funds only for the payment of civil servants' salaries and emoluments. The state governors often assume the roles of urban administrators, but most of the time efforts are concentrated on the state capital city which further fuelled emigration from the other settlements to the capital city (Adeyinka et al. 2016, Oyesiku 1999). Today, there is a general drive by state governments to improve urban administrations in the capital cities through installations of modern procedures and computerised systems to assist in urban land allocation, infrastructural facility management, traffic control and administration, urban security and administrations but holistic urban administration is alien to Nigeria (Fabiyi, 2017).

The nature of local government after Independence increased the subordination to central government established in the colonial period, with an even weaker fiscal base yet with considerably expanded areas of administration and burgeoning urban populations (Jenkins, 2000). There is no doubt that the 1999 constitution of Nigeria and local government statutes usually stipulate what local governments should do, but in practice they fail to articulate the roles of the different actors in urban administration.

\section{Towards Sustainable Urbanization in Nigeria}

It has been argued that commitment to sustainable development both for the present and future generations will be meaningless if collaborative approach is not employed (Oyeshola et al., 2009). Thus, it would be beneficial to assert that the solution to the lingering urban problems in Nigeria does not reside in proffering new policies per-se, but in the determination of all those involved in formulating and implementing urban policies to address the problems of growth in cities. However, one of the major threats to sustainable urban growth in Nigeria is poverty. In Nigeria, poverty is defined as a state of long-term deprivation of well-being, a situation considered inadequate for a decent life. It is synonymous with lack and is also a long-term phenomenon (Fourchard,2003). A World Bank data has revealed that 60 percent of Nigerians live below the poverty line, only 50 per cent of the population has access to safe water, and about 38 per cent do not have access to primary health care (World Bank, 1996). Thus, poverty jeopardizes the political stability, social cohesion and environmental balance of our cities, and until it is tackled decisively, sustainable development will remain a mirage (Olanrewaju, 2003).

The explosive rates of growth have not only progressively complicated and exacerbated inter-related problems of human settlements and environment, but have also greatly accelerated poverty (Oladunjoye, 2005). The issue of poverty needs to radically examined and accorded all the attention it deserves if achieving sustainability is anything to go by. The need to ensure sustainability in our cities is imperative and this depends largely on the application of the principle of sustainable development advocated by the Commission on Environment and Development - whereby, developmental efforts should not only concentrate on solving present problems but also consider future challenges and 
needs. Central to the issue of achieving sustainable urban growth is the need for good governance. This should be in accordance with the principles entrenched in the United Nations global Agenda 21; which seek to employ sustainable development strategies to integrate all aspects of development socially, economically, culturally and environmentally in achieving distributional equity and providing adequate social services including health, education, housing as well as functional and livable environment among many others. However, one peculiar feature of governance in Nigeria is the use of Top-down approach to policy formulation and implementation.

Consequently, policies and programmes emanating from such approach have continually rubbed the urban poor of their dignity (Onakuse \& Lenihan, 2017). Therefore, any worthwhile institutional approach in governance must consider among others: greater involvement of NGOs and community groups in local governance, greater transparency and accountability in both planning and implementation of local policy and the devolution of responsibility for urban affairs from state or national level to the local level. These are inevitable as the problems of urbanization can only be dealt with in an atmosphere of peace, better leadership (devoid of corruption) and freedom, especially in a politically frayed and frazzled continent as Africa. And as a major characteristic of good urban governance; decentralization of power, authority and responsibilities aids effectiveness as well as reaching out to the grassroots (Adegun, 2019).

\section{Concluding Remarks}

There is no doubt that the world has increasingly become urban and the 21st century witnessed rapid and unprecedented urbanization of the world's population. The pattern, trend, and characteristics of urbanization in Nigeria have been alarming. The towns and cities have grown phenomenally. Consequently, there has been rapid expansion of Nigerian cities' area up to 10-fold their initial point of growth and the fact that the growth has been largely unplanned and uncontrolled. This has shown that managing urban growth and urbanization in Nigeria have become one of the most important challenges of the 21st century. Local governments in many developing countries like Nigeria rarely have the mandate and/or capacity required to undertake planning let alone planning for sustainable development. Nor do they often have a mandate to plan or implement major items of strategic infrastructure needed to achieve such growth. While decentralization has provided opportunities for local government to take greater responsibility for the delivery of services, efficacy is often dependent upon the national and state governments providing appropriate enabling environments and supportive relationships to ensure they can operate efficiently.

This paper has examined the need for effective governance in the realization of sustainable urbanization in Nigeria. The paper notes that Urbanization is a global issue and an inevitable phenomenon in Nigeria. It observes that the pervasiveness and spontaneity associated with the urban growth process in Nigeria has been an issue of concern; as it essentially constitutes serious socio-economic, cultural and environmental challenges to the attainment of sustainable development and effective urban governance. This problem of spontaneous urban growth has been necessitated by the features of globalization, industrialization and population explosion, with its attendant challenges of uncontrolled growth of cities, which has led to a degraded environment and poor living standard of the 
people. Considering that growth within the context of urbanization should be guided towards improving the environment rather than harming it (Newman, 2002); this growth according to the concept of "sustainable development" must be sustainable in order to take care of the present needs without compromising the ability of future generation to meet its own needs.

Nevertheless, in line with the objective of this paper, it recommends the following:

- One major challenge of local government is the lack of financial autonomy to implement programmes at the grassroot level,therefore to engender sustainable urbanization,there is need for local government to have strong economic base,this is achievable through the upward review of the revenue sharing formulae among level of governments in Nigeria and strict adherence to NFIU guidelines by Nigerian governors.(Adedire 2014,Onyedika 2020)

- A participatory, multi-stakeholders 'and collaborative approach to policy making and implementation in reference to urbanization should be put in place as its an ideal requirement to achieving an ideal sustainability. (William et.al 2002, Mabogunje\&Robert,2004;Gille 2019)

- Sustainable development according to Odigbo\&Adeniran (2004) in Adedire (2014) is human focused, long term,enduring and not a quick fix. Local government can serve this role in relation to urbanization by consciously building a structural foundation on which urbanization can thrive, such foundation will re-orientate our valve system as well as encourage private initiatives and propagate cooperative philosophy.

\section{References}

1. Abiodun, J. O. (1997). The challenges of growth and development in Metropolitan Lagos”. In, C. Rakodi (Ed). The Urban challenge in Africa. Growth and Management of its large Cities. UN University Press. NY.

2. $\quad$ Adedire, S.A.(2014),Local Government and the challenges of Rural Development in Nigeria 1999 to date. Journal of Humanities and Social Science19(4)

3. Adegun, O. B. (2019). Shelter and the future African city. The Built \& Human Environment Review. $4(2)$

4. Adesina, A. O. (2003). Legibility and the Nigerian Urban Environment. Experiences from Ilorin: In, V. Adekunle et al. (Eds.). Proceedings of the Conference on the Challenges of environmental sustainability in a democratic governance. Environment and Behaviour Association of Nigeria. Lagos, Nigeria.

5. Ajayi K (2000). Justification and theories of Local Government. Theory and Practice of Local Government. Ado-Ekiti: Department of Political Science. University of Ado-Ekiti.

6. Ayoade A.O (2016),Employment generation through entrepreneurial development; The Nigerian experience. British Journal of Economics, Management and Trade 11(3)

7. $\quad$ Akinwotu, E., (2017). The rural-urban divides in Nigeria. The Guardian Newspaper.

8. $\quad$ Appadorai, A. (1975): The Substance of Politics, Oxford, Oxford University Press.

9. Asandului, M., Lupu, D., Maha, L. G., \& Viorică, D. (2021). The asymmetric effects of fiscal policy on inflation and economic activity in post-communist European countries. Post-Communist Economies. https://doi.org/10.1080/14631377.2020.1867430

10. Azu, V.N, (2018). Issues and challenges of urban governance in Africa: The Nigerian Experience. Global Journal of Political Science and Administration .6(2)

11. Berliner, J (1977). International migration: A comparative disciplinary view, In International Migration: A Comparative Perspective, ed. A, Brown, E. Neuberger,. New York: Academic 
12. Daramola, A. \& Ibem, E. O. (2018) Urban Environmental Problems in Nigeria: Implications for Sustainable Development. Journal of Sustainable Development in Africa. 12 (1)

13. Duru E,C \& Ogbonnaya U.M(2012) The Political and economics condition of the Institutionalism of Urban policies in Nigerian since the 20 Century. Journal of Social Science and Development issues 19(2) 14. Egboje, M.J., (2018). The unending challenges of rural sector in Nigeria. Kano: Abdullahi Karaye Printers.

15. Enemuo, F. C. (2008): "Decentralisation and Local Government: models. Principles and purpose" in Anifowose, R. and Enemuo F. (eds) Elements of Politics, Lagos, Sam Iroanusi Publishers.

16. European Environment Agency (2016). Urban sprawl in Europe - The ignored challenge. EEA Report No. 10/2016._pdf

17. Fabiyi O.O. (2014). The value of geospatial technology in town planning practice in Nigeria. Workshop proceedings of the Association of Town Planning Consultants of Nigeria 2014 Professional Development Workshop on Application of Emerging Cutting Edge Technologies in Town Planning Practice. 18. Fabiyi, O. (2017). Urban Space Administration in Nigeria: Looking into Tomorrow from Yesterday. Urban Forum.

19. Fourchard, L. (2003). Urban Slums Reports: The case of Ibadan, Nigeria. Understanding Slums: Case Studies for the Global Report on Human Settlements. Institut Francais de Recherche en Afrique (IFRA), University of Ibadan, Nigeria.

20. Gille, A. (2019). City Development Strategies in the City of Kampala. An analysis of participatory development in practice. Department of Physical Geography and Ecosystem Analysis University of Lund, Sölvegatan 1222362 Lund, Sweden

21. Hawley, A., (1981), Urban Society: An Ecological Approach, Ronald, New York.

22. Jenkins, P. (2000). Urban management, urban poverty and urban governance: planning and land management in Maputo. Environment \& Urbanization. 12(1) https://doi.org/10.1177/095624780001200110

23. Jiboye, A. D. \& Omoniyi, S. S. (2018). Environmental Sustainability and urban growth in Nigeria. Journal of Environmental Research and Policies. 5 (1)

24. Kasarda, J. D. \& Crenshaw, E. M. (1991) Third World Cities: Dimensions, Theories and Determinants, Annual Review of Sociology,(17).

25. Lenski, G\& Nolan, P (1984). Trajectories of development: A test of ecological evolutionary theory. Soc Forc.

26. Mabogunje, A. (1985). Towards an urban policy in Nigeria. In, P. Onobokun. (Ed.). Housing in Nigeria. A book of readings. Ibadan, Nigeria. NISER.

27. Mabogunje, A. L. \& Robert, W. K. (2004). Sustainable Development in Ijebu-Ode, Nigeria: The Role of Social Capital, Participation, and Science and Technology. CID Working Paper No. 102, Cambridge, MA: Sustainable Development Program, Center for International Development, Harvard University.

28. Newman, P. (2002):: A whole Sustainability and Planning government approach. An oration Text. Barnet, Melbourne.

29. Nolan, P \& Lenski, G (1985). Technoeconomic heritage, patterns of development, and the advantages of backwardness. Soc. Forc.

30. Obeng-Odoom, F. (2017) 'Urban Governance in Africa Today: Reframing, Experiences, and Lessons', Growth and Change, 48(1), https://doi.org/10.1111/grow.12164

31. Ofuebe, C., (1992). Organising the Nigerian peasantry for rural development: The case for effective education in rural cooperatives. In, M.S.O. Olisa \& J.I. Obiukwu (Eds.), Rural Development in Nigeria: Dynamics and strategies. Awka: MEKSLINK Publishers.

32. Obot O \& Umoh A (2017), Boundary dispute and its implication on inter group relation in Nigeria, International Journal of advanced academic research 3(12)

33. Oladunjoye, A. O. (2005). Nigeria: Implementation of the Sustainable Cities Programme in Nigeria. Sustainable Cities Programme. Localizing Agenda 21 Programme. United Nations Programme for Human Settlements. (UN-HABITAT).United Nations Environment Programme (UNEP). Havana, Cuba.

34. Olanrewaju, D. O. (2003). "Sustainable environment and the poor. A keynote Address". In, V. Adekunle, et al. (Eds.). Proceedings of the Conference on the Challenges of environmental sustainability in democratic governance. Environment and Behaviour Association of Nigeria. Lagos, Nigeria.

35. Onakuse, S. \& Lenihan, E. (2017). Policies, Programmes, and Sustainable Development in Nigeria: A Critique. Africana. 1 (1). 42-58. 
36. Onyedika A.(2020),Unending wait for financial autonomy for local council. Guardian Newspaper March 3

37. Osasona C., Ogunshakin L. \& Jiboye A. (2017). "The African Woman’s right to security Through sanitation. From the dwelling unit to the neighbourhood”. Conference proceeding on, Right to Live in Africa. Trieste, 9 - 10 November. University of Trieste, Italy.

38. Oyesiku, K \& Alade, W. (2018) "Historical development of urban and regional planning in Nigeria” State of planning report, Nigerian Institute of Town Planners.

39. Prahalad, C.K. \& A. Hammond, (2002). Serving the world's poor, profitably. Harvard Business Review, 80(9)

40. Smith, D.A., (1996), Third World Cities in Global Perspective: The Political Economy of Uneven Urbanization, Westview Press, Boulder, Colorado.

41. Ujoh, F. Kwabe, I. D. \& Ifatimehin, O. O. (2018). Understanding urban sprawl in the Federal Capital City, Abuja: towards sustainable urbanization in Nigeria. Journal of Geography and Regional Planning. 3 (5). https://doi.org/10.5897/JGRP.9000151

42. United Nations (2002). World Population Prospects: The 2001 Revision. Data Tables and Highlights. United Nations. Department of Economic and Social Affairs. Population Division. New York.

43. United Nations, (2017). Achieving the Millennium Development Goals in Nigeria. How Far Now? UN-Habitat' United Nations Week. Abuja, Nigeria.

44. United Nations Development Action Policy,(2015),Revised draft of habitat county program document. Nigeria (2015-2017)

45. William C. C. (2002). Science and Technology for Sustainable Development: Initiative on Science and Technology for Sustainability. Consensus Report of the Mexico City Synthesis Workshop, May, 20-23, 2002. Cambridge, M. A.

46. World Bank. (1996). Poverty in the Midst of Plenty: The Challenge of Growth with Inclusion. Report no. 14733, Washington D.C. Creative Commons Attribution - Non Commercial - No Derivatives 4.0 International License. 